\title{
Seasonal life cycle of the tropical cricket Eneoptera surinamensis (Orthoptera, Gryllidae, Eneopterinae)
}

\author{
Edison Zefa, Fernando M. Rúbio, Alcides R. Rinaldi, Luis H. Gollin, \\ Denis B. F. da Silva \& Pedro G. B. S. Dias
}

Departamento de Zoologia e Genética, Universidade Federal de Pelotas (UFPel), 96010-900 Capão do Leão, RS, Brasil.

\begin{abstract}
The life cycle and seasonal distribution of a tropical population of Eneoptera surinamensis (De Geer, 1773) were analyzed aiming to verify whether this species life cycle is associated to the wet and dry seasons. The population studied was found at the Seasonal

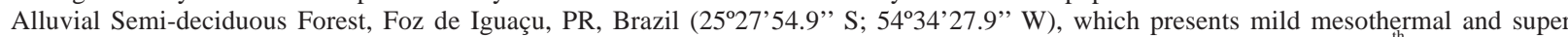
humid climate. Field observations were made at 20- to 24-day intervals, with the first observation occurring on April $30^{\text {th }}, 2002$ and the last on April $25^{\text {th }}, 2003$. It was verified that the studied species is univoltine and cyclic with regards to the dry and wet seasons, therefore being heterodynamic and surviving the dry season as adult.
\end{abstract}

KEYWORDS. Gryllidae, seasonal distribution, univoltine, heterodynamic.

RESUMO. Ciclo de vida e distribuição sazonal do grilo tropical Eneoptera surinamensis (Orthoptera, Gryllidae, Eneopterinae). $\mathrm{O}$ ciclo de vida e a distribuição sazonal de uma população tropical de Eneoptera surinamensis (De Geer, 1773) foram analisados com o objetivo de verificar se o ciclo dessa espécie tem associação com as estações secas e úmidas. A população analisada encontra-se na Floresta Estacional Semidecidual Aluvial, Foz do Iguaçu, PR, Brasil (2527'54.9” S; 54³4'27.9” W), a qual apresenta clima mesótermico brando superúmido sem seca. As observações em campo foram realizadas em intervalos de 20 a 24 dias, sendo que a primeira observação ocorreu no dia 30/04/2002 e a última em 25/04/2003. Verificou-se que a espécie estudada é univoltina e cíclica em relação às estações secas e úmidas, sendo dessa forma heterodinâmica, sobrevivendo à estação seca como adultos.

PALAVRAS-CHAVE. Gryllidae, distribuição sazonal, univoltino, heterodinâmico.

Nine different patterns of life cycles are known in crickets (MASAKI \& WALKER, 1987; WALKER \& MASAKI, 1989). These patterns are primarily characterized by the presence of photoperiodically and thermally controled diapause and developmental responses (heterodynamic) or by the absence of such responses (homodynamic) (MASAKI, 1996).

In the homodynamic life cycles there are populations with continuous growth and reproduction, in other words, all developmental stages are present at all seasons. Such life cycles are restricted to tropical and subtropical latitudes in which information concerning the life cycle of crickets is scarce. Heterodynamic life cycles are characterized by populations that have their growth and reproduction adjusted to the year's seasons (MASAKI \& WALKER, 1987).

The stage of winter survival is used as a reference in the characterization of the life cycle, given that the development of the individuals of any given population is synchronized at this stage. The use of this stage as a basis for the classification of heterodynamic life cycles reflects the fact that the seasonal cycles of crickets have been studied almost exclusively in temperate climates (Masaki \& Walker, 1987; Walker \& Masaki, 1989).

In tropical and subtropical regions, numerous species of crickets are supposedly cyclic in relation to the dry and wet seasons (AleXANDER, 1968; MASAKI \& WALKER, 1987; WALKER \& MASAKI, 1989; MASAKI, 1996).

Most of the species of temperate climates overwinter in the form of eggs, some as juveniles, and few as adults. Most present a single generation per year (univoltine), although some are bivoltine (two generations per year) and a few are semivoltine (one generation every two years) (WALKER \& MASAKI, 1989).

Crickets of the subfamily Eneopterinae eat leaves, flowers and fruits of living plants, occasionally damaging species of value to man. They deposit their eggs in pith, bark, or soft wood of plant stems. The more than 500 species of this family are largely restrict to moist, tropical habitats (WALKER, 1997). Eneoptera surinamensis (De Geer, 1773) is one of the main representatives of this family, with high population densities and widely distributed in the Neotropical region.

Considering that the studies concerning the life cycle of crickets were developed almost exclusively at regions of temperate climates, in the present work the life cycle and seasonal distribution of a tropical population of $E$. surinamensis was analyzed, aiming to verify whether this species is cyclic in relation to the dry and wet season, as postulated by ALEXANDER (1968), MASAKI \& WALKER (1987), WALKER \& MASAKI (1989), and MASAKI (1996).

\section{MATERIAL AND METHODS}

The population studied is found at the semideciduous seasonal forest, located about $20 \mathrm{~km}$ from

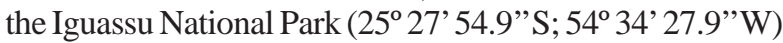
at $195 \mathrm{~m}$ above sea level.

The climate in the region has been classified as mild mesothermal and super humid. The annual mean precipitation rate is $1,650 \mathrm{~mm}$ with the main wet season occurring between October and January. The highest 
temperatures are also registered during this period, reaching $40^{\circ} \mathrm{C}$ in January. The lowest temperatures are registered during the dry season, from May to August, varying from 2 to $5^{\circ} \mathrm{C}$ in the coldest days. The annual mean temperatures vary from 18 to $20^{\circ} \mathrm{C}$. The air relative humidity is permanently high and, even during the driest period, is seldom registered below 80\% (GUIMARÃES et al., 2003).

Field observations were conducted at 20- to 24day intervals. The first one occurred on April 30 ${ }^{\text {th }}, 2002$ and the last on April 25 ${ }^{\text {th }}, 2003$, totalling 18 field observations.

Observations were made between 5:00 and 9:00 pm, approximately, and some specimens were collected in order to characterize their developmental stage, which was determined considering body size, developmental degree of ovipositor, wing buds, and tegmen, since there are no studies concerning the number of instars presented by this species.

The reproductive stage was characterized by the emission of the calling song by the males in order to attract the females.

\section{RESULTS}

Adults of E. surinamensis were found during the field observations performed in the months from April to mid-December. The calling activity of stridulation that indicates the mating stage of this species occurred from July to December, a period that included the transition between the wet and dry months. No adult of $E$. surinamensis was observed from mid-December until March (Tab. I).

A large number of nymphs at different developmental stages were found during the observations made from December until mid-March and their rapid development accompanied the sprouting of the vegetation. Pre-adults were observed in the months of February and March while the first imagoes occurred in April, together with an exuberant vegetation that sprouted after the rainy months (Tab. I).

\section{DISCUSSION}

The adult life of crickets is relatively long, given that adults of either sex survive about 2 to 3 months, and even over 6 months in some extreme cases (MASAKI \& WALKER, 1987). Among the most long-lived crickets are the semivoltine Gryllotalpa africana Beauvois, 1805 (from Spain) and Nemobius sylvestris (Bosc, 1792) (from England), which present 12 and 9 months of adult life, respectively (ALEXANDER, 1968). Although characterized as univoltine, E. surinamensis is found in adult stage during approximately 8 to 9 months; this fact corroborates the supposition of ALEXANDER (1968) that tropical adult crickets survive for longer periods than their adult counterparts of temperate climates.

The long duration of the adult stage of $E$. surinamensis includes the driest months of the year, thus suggesting a period of diapause involving the three months that precede the beginning of the mating season, which is easily recognized by the emission of the calling song by the males in order to attract the females. This period includes the months when the vegetation is less exuberant and consequently offers fewer nutrients. Nevertheless, such a supposition should be confirmed through physiological analyses.

Although there are no data concerning a diapause period in E. surinamensis, we observed that the synchronization of the development of the biological cycle in the population studied took place at the adult stage, mainly during May and June. During the mating season that lasts about 6 months, a non-synchronized oviposition probably occurs from September to December, with egg eclosion thus occurring in different periods. This fact was verified by the presence of nymphs at different developmental stages from December to March.

Given that the synchronization of the life cycle of E. surinamensis took place during the driest season, we consider that the supposition of ALEXANDER (1968) and WALKER \& MASAKI (1989) suggesting that wet and the dry season have a synchronizing effect on the life cycle of crickets, is confirmed in the population of $E$. surinamensis studied in the present work.

According to our results and based on the types of life cycles proposed by ALEXANDER (1968), MASAKI \& Walker (1987), Walker \& Masaki (1989), and MASAKI (1996), the species E. surinamensis is cyclic with regards to the dry and wet seasons, therefore being characterized as heterodynamic, overwintering during its adult stage, and showing one generation per year (univoltine)

Acknowledgements. We would like to thank Akio R. Myoshi (Universidade Estadual Paulista, UNESP, Rio Claro) for his encouragement and suggestions and Sandra Bergmann for her help in collecting the examples analyzed.

Table I. Diagram of the life cycle of the E. surinamensis. The black bar indicates the presence of specimens (*, deduced data).

\begin{tabular}{|c|c|c|c|c|c|c|c|c|c|c|c|c|}
\hline & Jan & Feb & Mar & Apr & May & Jun & Jul & Aug & Sep & Oct & Nov & Dec \\
\hline \multicolumn{13}{|l|}{ Eggs* } \\
\hline \multicolumn{13}{|l|}{ Nymphs } \\
\hline \multicolumn{13}{|c|}{ Pre-adults } \\
\hline \multicolumn{13}{|l|}{ Adults } \\
\hline \multicolumn{13}{|l|}{ Mating } \\
\hline Seasons & wet & & & & dry & dry & dry & dry & & wet & wet & wet \\
\hline
\end{tabular}




\section{REFERENCES}

AleXander, R. D. 1968. Life cycle origins, speciation and related phenomena in crickets. The Quarterly Review of Biology 43(1): 1-41.

Guimarães, A. E.; Lopes, C. M.; Mello, R. P. \& Alencar, J. 2003. Ecologia de mosquitos (Diptera, Culicidae) em áreas do Parque Nacional do Iguaçu, Brasil. 1 Distribuição por hábitat. Caderno de Saúde Pública 19(4): 1107-1116.

MasAKI, S. 1996. Geografical variation of life cycle in crickets
(Ensifera: Grylloidea). European Journal of Entomology 93:281-302.

Masaki, S. \& Walker, T. J. 1987. Cricket life cycles. Evolutionary Biology 21:349-423.

Walker, T. J. 1997. Eneopterinae: bush crickets. Chapter 24; prepared for handbook of crickets and Katydids, an inactive project. Available at: <http://buzz.ifas.ufl.edu/ s6711w97.pdf>. Access on: 02.11.2004.

Walker, T. J. \& Masaki, S. 1989. Natural history. In: Huber, F.; Moore, T. E. \& Loher, W. eds. Cricket behaviour and Neurobiology. Ithaca, Cornell University. 42p. 